\title{
LIMITES E POSSIBILIDADES DO ARCABOUÇO ANALÍTICO DE CHALMERS JOHNSON PARA COMPREENDER A ESTRATÉGIA INDUSTRIAL: UM OLHAR INSTITUCIONALISTA SOBRE A ECONOMIA POLÍTICA DA CHINA
}

Luiz Fernando de Paula ${ }^{1}$ Rafael Moura ${ }^{2}$

Resumo: Um dos mais notórios acontecimentos do último quarto do Século XX foi a modernização socioeconômica, tecnológica e produtiva do Leste Asiático, em especial Japão, Coreia do Sul e Taiwan. Já a partir da virada do século e continuando no presente, a República Popular da China (RPC) entraria neste grupo de nações exitosas se consolidando como potência em contínua trajetória de crescimento. Diversos enfoques teóricos buscaram explicar o sucesso desses casos, dentre eles do Estado Desenvolvimentista (ED), elaborado originalmente por Chalmers Johnson em 1982. O presente artigo objetiva fazer um balanço crítico da literatura desenvolvimentista relacionada à estratégia industrial da China, além de examinar em que medida a economia política chinesa se adequa ou não aos quatro predicados institucionais do ED elucidados pelo autor.

Palavras-chave: China. Estratégia Industrial. Economia Política. Instituições. Estado Desenvolvimentista.

\section{LIMITS AND POSSIBILITIES OF CHALMERS JOHNSON'S ANALYTICAL FRAMEWORK FOR UNDERSTANDING THE INDUSTRIAL STRATEGY: AN INSTITUTIONALIST LOOK AT CHINA'S POLITICAL ECONOMY}

Abstract: One of the most notorious events of the last quarter of the XXth century was the socioeconomic, technological and productive modernization of East Asia, in particular Japan, South Korea and Taiwan. In the turn of the century and continuing in the present, the People's Republic of China (PRC) entered this group of successful nations consolidating itself as a superpower in a continuous growth trajectory. Several theoretical approaches sought to explain the success of these cases, among them that of the Developmental State (ED), originally developed by Chalmers Johnson in 1982. This article aims to make a critical assessment of the developmentalist literature focused on China's industrial strategy, in addition to examining the extent to which the Chinese political economy fits or not the four institutional predicates of the DS elucidated by the author.

Keywords: China. Industrial Strategy. Political Economy. Institutions. Developmental State.

\section{LÍMITES Y POSIBILIDADES DEL MARCO ANALÍTICO DE CHALMERS JOHNSON PARA COMPRENDER LA ESTRATEGIA INDUSTRIAL: UNA MIRADA INSTITUCIONALISTA A LA ECONOMÍA POLÍTICA DE CHINA}

\footnotetext{
${ }^{1}$ Universidade Federal do Rio de Janeiro, Instituto de Economia, Rio de Janeiro, Brasil; e Universidade do Estado do Rio de Janeiro, Instituto de Estudos Sociais e Políticos, Rio de Janeiro, Brasil, luizfpaula@terra.com.br, https://orcid.org/0000-0001-9770-516X

2 Universidade do Estado do Rio de Janeiro, Instituto de Estudos Sociais e Políticos, Rio de Janeiro, Brasil, rafaelmoura5028@gmail.com, https://orcid.org/0000-0003-4185-4005
} 
Resumen: Uno de los hechos más notorios del último cuarto del siglo XX fue la modernización socioeconómica, tecnológica y productiva del este de Asia, en particular Japón, Corea del Sur y Taiwán. A partir del cambio de siglo y continuando en el presente, la República Popular de China (PRC) entraría en este grupo de naciones exitosas consolidándose como potencia en trayectoria de continuo crecimiento. Varios enfoques teóricos buscaron explicar el éxito de estos casos, entre ellos el Estado Desarrollista (ED), originalmente elaborado por Chalmers Johnson en 1982. Este artículo tiene como objetivo hacer una evaluación crítica de la literatura desarrollista relacionada con la estrategia industrial de China, además de examinar la medida en que la economía política china encaja o no con los cuatro predicados institucionales del ED aclarados por el autor.

Palabras clave: China. Estrategia Industrial. Economía Política. Instituciones. Estado Desarrollista.

\section{Introdução}

Nas últimas duas décadas do Século XX, a região geográfica denominada como Leste Asiático ganhou grande destaque de acadêmicos, analistas internacionais e autoridades políticas em função de sua modernização socioeconômica e catching-up, que elevou seus níveis de renda e sofisticou seus regimes produtivos vis-à-vis os países mais ricos do Ocidente (FALLOWS, 1994; CHANG, 2006). ${ }^{3}$ Começando com o Japão, e depois prosseguindo com Coreia do Sul, Taiwan, e, por fim, a China em escala bem superior, esse grupo de quatro países em 2018 representava $24,5 \%$ da economia mundial, ante $10,79 \%$ em 1970 (WORLD BANK, 2020; REPUBLIC OF CHINA, 2020).

A partir dessas trajetórias, diferentes narrativas buscaram mapear os elementos comuns responsáveis pelo sucesso da região. Destas, uma das mais proeminentes é a do Estado Desenvolvimentista (ED) ou institucionalismo endógeno. Emergente a partir do livro seminal de Chalmers Johnson de 1982 sobre a experiência industrializante japonesa, daria corpo a uma ampla literatura voltada para análise do processo de desenvolvimento dos demais países asiáticos, donde se destacariam também autores como Alice Amsden (1989), Robert Wade (1992), etc. Sua ênfase analítica estava nas políticas governamentais e instituições domésticas dos casos nacionais, e como contribuíram ao desenvolvimento econômico subsequente.

\footnotetext{
3 "Catching-up" ou emparelhamento são termos utilizados de forma recorrente na literatura econômica de corte mais heterodoxo e estruturalista, referindo-se à diminuição do hiato de renda e produtividade das nações pobres com relação às ricas industrializadas, logrando posições melhores no que tange à divisão internacional do trabalho e traduzindo uma curva de aprendizado de bens com conteúdo de conhecimento ou tecnológico menos para mais elevados (REINERT, 2016).
} 
Ao passo que a produção teórica dos autores dessas vertentes citadas prosseguiu ao longo da década de 1990, atualizando o debate de forma recorrente, a partir dos anos 2000 em diante a ascensão chinesa e a sua consolidação mais nítida enquanto potência global acrescentou um novo ingrediente às discussões gerais de economia política. Afinal, tratava-se da corrida ideológica pela interpretação fidedigna do país que, num intervalo de aproximadamente três décadas, operou um verdadeiro "milagre": entre 1978 e 2008, o PIB e o PIB per capita da China cresceram em média, respectivamente, 10,02\% e 8,82\% ao ano em média nesse período (WORLD BANK, 2020).

Além desta introdução, este artigo está estruturado da seguinte forma: na seção seguinte, debatemos a interpretação do Estado Desenvolvimentista acerca do êxito do Leste Asiático, apontando suas virtudes e limitações em termos explicativos para a região no seu devido cenário histórico, político, econômico e social; assim como as razões pelas quais optamos por tal literatura para analisar o processo de desenvolvimento da República Popular da China (RPC), não obstante suas eventuais incompletudes. A terceira seção, por vez, objetiva uma radiografia a fundo de expoentes que esmiúçam a trajetória chinesa reivindicando uma matriz analítica desenvolvimentista. Esse balanço crítico será feito a partir da medida em que se aproximam ou distanciam dos predicados e condições institucionais antes apontados por Johnson como imperativos à existência do ED. A quarta seção, em seu turno, num recorte temporal percorrendo desde as reformas institucionais a partir do líder Deng Xiaoping em 1978 até a crise financeira de 2008, reconstitui a história de sua economia política enfatizando a estratégia industrial e suas instituições de sustentação. Assim, buscamos avaliar em que medida o país se adequa ou não o conceito canônico do autor (ED). A última seção traz as considerações finais ao artigo.

\section{A narrativa do Estado Desenvolvimentista do Leste Asiático: Sua emergência, méritos e deméritos analítico-explicativos}

Esta seção analisa criticamente, através de expoentes canônicos selecionados, o corpo teórico responsável pela interpretação do Estado Desenvolvimentista, explicando em seguida os motivos pelos quais escolhemos tal literatura e a consideramos superior - em termos de coerência argumentativa - para executar nosso estudo das transformações engendradas na China. Surgida em 1982, não focava originalmente sobre a região, mas sim sobre o sucesso particular japonês em sua reconstrução e desenvolvimento com mudança estrutural no Pós- 
Guerra, ascendendo exitosamente nas cadeias produtivas globais. Desta forma, através da obra "MITI and the Japanese Miracle: The Growth of Industrial Policy, 1925-1975", Chalmers Johnson (1982) identificou e mapeou as instituições e organizações políticas e econômicas explicativas de tal trajetória.

No livro, mostra como o Estado, através de distintas formas e mecanismos, foi a engrenagem política derradeira facultando o desenvolvimento na industrialização tardia nipônica. Esta engrenagem só foi possível graças a quatro pilares fundamentais: 19) Uma burocracia decisória competente responsável por formular, implementar e supervisionar uma política industrialista enfática sobre setores designados como estratégicos, sendo composta pelos "melhores talentos disponíveis" e gozando de autonomia e insulamento relativos ante os grupos políticos de interesse e seus respectivos lobbies; $2^{\circ}$ ) Um sistema político que dê ao Poder Executivo e sua burocracia grande margem de manobra decisória e autonomia com relação aos correlatos do Legislativo e Judiciário sobre a agenda governamental; $3^{\circ}$ ) Intervenções estatais em conformidade com os princípios de uma economia de mercado; e, por fim, 4⿻) Uma agência-piloto ou órgão nuclear responsável pelo planejamento da estratégia de desenvolvimento, estipulando metas industriais e controlando, direta ou indiretamente, fundos governamentais de modo a distribuí-los conforme os ditames da estratégia (JOHNSON, 1982: p.314-320).

Aqui cabe uma ressalva: com relação ao terceiro item, é preciso cuidado com a matização exata de "conformidade com princípios de uma economia de mercado". Pela terminologia, o autor não se refere a qualquer primazia institucional desse mecanismo enquanto alocador de preços e recursos na sociedade, mas sim à intervenção discricionária governamental consciente e consistente para direcionar o curso produtivo. Estes métodos, que traduzem as políticas e instituições arquitetadas na esfera econômica se dão mediante o que chama de orientação administrativa ou "administrative guidance" (JOHNSON, 1982). Este princípio diria respeito ao Estado, enquanto galvanizador da estratégia nacional de desenvolvimento, materializando uma relação cooperativa e simbiótica entre governo e os representantes do setor empresarial privado através da dialética entre incentivos e ordens de modo a obter o compromisso destes com o cumprimento das metas e, assim, viabilizar a chamada "racionalização industrial" (Sangyō Gōrika 産業合理化). Foi assim que o governo japonês interveio, portanto, mediante: criação de instituições financeiras de induzir à iniciativa privada via crédito; uso seletivo de incentivos tributários (exemplo: isenções setoriais); planos indicativos mapeando os 
caminhos futuros desejados para o desenvolvimento; investimentos ou uso de empresas públicas em nichos produtivos de maior risco e, por fim, o uso estratégico dos licenciamentos e aprovações governamentais (JOHNSON, 1982: p.318).

Já a agência-piloto referida no quarto item foi o Ministério do Comércio Internacional e Indústria ("Ministry of International Trade and Industry" ou MITI). Este, ao longo dos "anos dourados" da reconstrução e milagre japonês (1955-1975), constituiu o principal órgão planejador das políticas públicas e objetivos previamente citados, sendo também articulador da grande coalizão entre o incumbente Partido Democrático Liberal (LDP), a tecnoburocracia econômica e as elites empresariais dos grandes conglomerados - keiretsus - em torno do projeto de desenvolvimento nacional. Assim, via planos e metas setoriais do MITI identificando tecnologias estratégicas do Ocidente imprescindíveis ao catching-up, construiu-se um arcabouço institucional e regulatório facultando, de um lado, licenciamentos e joint ventures para apropriação das mesmas; e, de outro, estruturas industriais oligopolistas, cartelizadas e concentradas que, via economias de escala, dariam origem a "campeões nacionais" (os já aludidos keiretsus) competitivamente exitosos com o tempo (JOHNSON, 1982).

Depois da obra de Johnson, o contínuo êxito não só nipônico como dos países da região levou à reificação do debate e proliferação de outras produções intelectuais sobre tais economias políticas. Na esteira destas, em 1989 Alice Amsden lançaria o que viria a se tornar outra grande referência nessa literatura: “Asia's Next Giant: South Korea and Late Industrialization". Nele, a autora analisou a trajetória de modernização e catching-up de outro país asiático, a Coreia do Sul, iniciando sua análise com o governo de Syngman Rhee nos anos 1950 e prosseguindo através do regime militar sob o General Park Chung-Hee (1961-1979) e também parte do governo Chun Doo-hwan (1980-1987).

No livro mostra como o Estado sul-coreano, em contornos institucionais muito próximos aos do caso japonês, adquiriu um papel demiurgo e empresarial, também dando forma e fomentando grandes conglomerados empresariais - as chaebols que, graças às políticas protecionistas erigidas pelo governo, foram capazes de aprender novos processos produtivos, internalizando tecnologias e know-how dos EUA e do próprio Japão (AMSDEN, 1989). Examinando a fundo as facetas da dinâmica de crescimento do país, mostra que o êxito industrialista e exportador sulcoreano, em rigorosamente quase todos os setores produtivos engajados ao longo dos anos 1960, 1970 e 1980 (têxtil, naval, petroquímico, etc.), teve por trás a 
planificação governamental. Esta se deu, por sua vez, em termos de percepção de novas oportunidades econômicas, socialização de riscos em investimentos de maior maturação, alocação estratégica de recursos financeiros em setores prioritários através de bancos de fomento e sistema de crédito majoritariamente público, e outras muitas intervenções (lbid.).

A estratégia industrial, de forma análoga ao ocorrido no Japão, foi formulada e materializada inteiramente por iniciativa do Estado. O governo estipulou diversos planos quinquenais de desenvolvimento buscando substituição de importações e sofisticação de setores tais como cimento, fertilizantes, refino de petróleo, fibras sintéticas e têxteis, passando depois às indústrias pesadas com ênfase nos setores petroquímico e naval e, entre os anos 1970 e 1980, por fim, ao segmento de eletrônicos. Tudo isso foi possível em larga medida graças ao papel visionário desempenhado pelo Conselho de Planejamento Econômico ("Economic Planning Board'), órgão burocrático decisório que, em muitos sentidos, era análogo ao MITI e formulador unilateral de tais planos, que também estabeleciam metas de alocação de recursos e prazos para a materialização de projetos em consonância com a classe empresarial (AMSDEN, 1989: p.80-1).

Por fim, Robert Wade, também inserido em tal controvérsia sobre o papel das instituições formais na indução ao desenvolvimento na região, examinou em 1990 a trajetória da ilha de Taiwan à luz das experiências prévias do Japão e da Coreia do Sul. Lá, o governo do Partido Nacionalista (Kuomintang ou KMT) e de Chiang Kaishek, cujas bases políticas e militares de sustentação haviam fugido da China continental após a derrota na guerra civil, também logrou um milagre econômico. Novamente, com grande peso do governo nos monopólios produtivos e bancários, canalização de investimentos para setores-chave e uma inserção exportadora de base manufatureira, concomitante a pesados subsídios e protecionismos ante a concorrência externa, o país também logrou novas tecnologias por meio de aprendizado e parcerias com corporações estrangeiras; promovendo a acumulação de capital nacional (WADE, 1990).

Com uma perspectiva institucionalista de economia política destoante da neoclássica, estabeleceu portanto a "teoria do mercado governado" ("Governed Market Theory" ou GMT) como explicação para o sucesso do Leste Asiático e complemento à interpretação do ED. Segundo ela, o paradigma relacional entre governo e empresas na região foi definido exatamente pela liderança do Estado; criando múltiplas vantagens competitivas internacionais para favorecer indústrias 
nascentes e orientar o desenvolvimento de certas áreas ligadas à fronteira tecnológica e de crescimento da economia global (WADE, 1990: p.25).

Com a escolha destes três autores, não queremos dizer que a literatura neles se esgota ou que o debate se esvaneceu após a obra de Wade, mas sim trazer ao âmago do artigo as reflexões individuais mais extensas e detalhadas sobre os três casos nacionais em específico. Destarte, a interpretação ou narrativa do ED rapidamente ganhou destaque e possui, em nosso juízo, dois grandes méritos e duas problemáticas. O primeiro mérito é ter cunhado um arsenal analítico que, atenta às instituições e processos históricos, tornou-se um marco para estudos de economia política comparada. O segundo mérito dessa literatura é ter sobrevivido nadando "contra a corrente", num período onde consolidou-se outro mainstream econômico composto por múltiplas correntes de pensamento pondo em xeque a eficácia das ingerências governamentais nas variáveis de mercado. Tal mainstream, defendendo a retração do intervencionismo público nas áreas industrial e social, bem como a desregulamentação comercial e financeira, seria, no campo teórico, um ataque frontal às perspectivas do keynesianismo e da economia do desenvolvimento hegemônicas desde o Pós-Guerra (EVANS, 1993). Já no campo político, proveria sustentação ideológica aos emergentes governos de orientação neoliberal de Ronald Reagan e Margareth Thatcher (HARVEY, 2005). Assim, tais autores institucionalistas reificaram a importância do Estado-nação enquanto unidade analítica num momento onde sofria forte contestação.

Já a primeira das problemáticas assinaladas tange à idealização weberiana excessiva - e reducionista - feita da burocracia pública governamental e do próprio Estado. Ambos são corriqueiramente tratados na literatura como atores unitários e monolíticos, desprovidos de incoerências, contradições internas e alheios aos conflitos de interesses políticos quanto aos rumos do planejamento econômico (YEUNG, 2016; NOGUEIRA e HAO, 2018). A segunda problemática, por fim, seria o forte nacionalismo metodológico da literatura, sendo este definido como um quadro teórico-normativo de referência onde os fatores endógenos constituem as únicas chaves explicativas para o destino do ou dos países em questão, seja no caso de arcabouços institucionais mais estatistas, seja no de liberalizantes (GORE, 1996).

Não negamos que o desenho institucional das políticas de intervenção estatal e racionalização produtiva atuaram conjugadas aos fatores externos, mostrando capacidade dos governos e tecnoburocracias decisórias incumbentes de lerem corretamente o cenário com o qual se defrontavam. Destarte, sem desmerecer os 
fatores externos, reafirmamos que as instituições domésticas importam no construção de um projeto de desenvolvimento. Justamente por isto, a literatura do ED tem seu valor incólume, e é por essa razão que a elencamos como instrumental teórico-analítico para compreender a China. Na próxima seção, antes de enfim procedermos à aplicação dos pilares constitutivos do conceito para ver se encontra lastro ou não na RPC, tecemos um olhar crítico da literatura autointitulada desenvolvimentista que buscou estudá-la, mapeando sua acurácia e/ou imperfeições contribuintes ao melhor entendimento de nosso objeto de pesquisa.

\section{A China nas lentes do paradigma desenvolvimentista: Balanço crítico da literatura existente}

$\mathrm{Na}$ seção anterior, fizemos uma breve radiografia da narrativa do Estado Desenvolvimentista, enquanto uma das três literaturas mais destacadas nas análises comparativas (ou isoladas) dos casos nacionais de sucesso do Leste da Ásia, no que tange ao desenvolvimento econômico. Como também frisamos, a despeito das limitações e insuficiências, a interpretação do ED joga uma luz abrangente sobre esses processos de sofisticação e modernização social e produtiva, trazendo elementos e aportes válidos à compreensão da real natureza da interlocução entre Estado e mercado bem como os mecanismos propulsores do crescimento de caráter industrial em tais trajetórias.

No que tange à China em particular, por seu desenvolvimento exuberante e consolidação como polo manufatureiro mundial nas últimas décadas, diversos autores despertaram seu interesse sobre tal nação e analisaram, mais recentemente, o Império do Meio através de adaptações feitas da literatura desenvolvimentista original. Muitos, desejando aplicar ao caso chinês o rótulo de ED e enquadrá-lo no conjunto de transformações atentadas por Chalmers Johnson e a literatura posterior nele inspirada, flexibilizaram o conceito e distorceram seus sentidos equivalendo-o a intervencionismos governamentais sui generis sobre a atividade produtiva. Enquanto isso, outros teceram análises mais ricas e próximas aos eixos do tipo ideal. Esta seção do artigo analisa, portanto, leituras selecionadas que são declaradamente desenvolvimentistas a fim de elucidar suas contribuições ao debate, num eixo implícito dos autores mais distantes aos mais próximos dos predicados institucionais apontados por Johnson.

A autora inaugural desta radiografia é Li (2017). Em seus esforços de analisar a eventual adequação da China ao conceito de ED, tomando os casos clássicos de Japão, Coreia do Sul e Taiwan como referência, enriquece o debate por salientar a 
dimensão política, muito ausente na literatura tal como frisado na Seção II. Li, contudo, faz uma ressalva compreensível a tal negligência: tais casos nacionais, durante o recorte temporal da fase mais pujante do catching-up, eram regimes em boa medida autoritários onde os partidos e/ou líderes incumbentes governavam com supressão dos pouquíssimos (ou inexistentes) atores políticos opositores de relevo.

Não obstante, em tal empreitada, Li (2017) acabou negligenciando dimensões importantes dos desenhos institucionais focados pela literatura, com analogia simplória entre o "desenvolvimentismo" dos governos nacionais e a capacidade da estrutura estatal formal para formular, implementar e reforçar políticas prócrescimento. Conforme a autora, a utilidade analítica das capacidades estatais se revela na investigação da dinâmica das relações do governo com as elites políticas e grupos societais no curso do desenvolvimento. $\mathrm{Na}$ esteira dessas lentes interpretativas, não se trataria se a China seria ou não um Estado Desenvolvimentista, mas sim quando deteria essa qualidade efetivamente. Assim, portanto, centrada no policymaking, considera que o Estado detém inclinação "mais desenvolvimentista" ao implementar medidas para transformação econômica nacional que imponha perdas materiais e/ou políticas substantivas a segmentos privilegiados da sociedade. De forma antípoda, o Estado não 0 seria (desenvolvimentista) ao hesitar ou negar sua aplicação para não incorrer em prejuízos aos interesses ossificados nos arranjos estruturais (sociais e produtivos) vigentes.

No que compreende o caso chinês pós-reformas, Li (2017) crê que o país tenha passado por "hiatos" de desenvolvimentismo conforme particularidades de cada contexto político. Do fim dos anos 1970 até fins dos anos 1980, a descoletivização no meio rural e descentralização de poderes decisórios e fiscais indicaram aumento de tal capacidade do Estado, por imporem o esvaziamento relativo dos poderes dos grupos políticos defensores da planificação central e crescimento dos preços dos gêneros alimentícios para cidadãos urbanos, representando o fim de um privilégio que possuíam vis-à-vis o meio rural durante a era maoísta. Não obstante, Li não especifica que grupos políticos "perdedores" foram esses nem matiza suas "perdas" acumuladas, o que dificulta a validação de seu argumento.

Entre fins da década de 1980 até meados da de 1990, por sua vez, a capacidade desenvolvimentista do governo chinês teria sido supostamente declinante em função dos imbróglios e indefinições após os protestos de Tiananmen 
(1989) e litígios políticos internos dentro do PCCh, resultando num recuo parcial do processo reformista de abertura para atendimento de interesses de grupos "conservadores" dentro do partido. Outra vez, contudo, a autora não destaca, possivelmente pelas restrições de escopo de seu capítulo, que atores políticos compunham tal grupo, a quais nichos vestidos em instituições pertenciam nem seus setores societais de suporte. Mas, com o governo de Jiang Zemin a partir de meados daquela década, aponta que teria ocorrido novamente a retomada do fortalecimento da capacidade desenvolvimentista do Estado chinês em vista da recentralização fiscal e de novas instituições (principalmente bancárias) concentrando crédito e margem de alocação financeira nas mãos do governo.

Embora detenha elo com os caminhos históricos percorridos por alguns países do Leste Asiático e rupturas sociais antecedentes às suas decoladas (ex: reformas agrárias), a concepção desenvolvimentista de Li centrada na disposição para impor prejuízos a grupos de poder ou elites políticas mais se assemelha à perspectiva institucionalista dos autores Kent Weaver e Bert Rockman em seu trabalho clássico (1993) sobre capacidades estatais. Tampouco explora as contradições emergentes do suposto desenvolvimentismo do Estado chinês na década de 1980 em meio a uma descentralização (relativa) do poder político e fiscal. Por fim, a autora também desconsidera a possibilidade de um governo ou coalizão em determinado país promover o crescimento ou bons resultados econômicos sem necessariamente ser desenvolvimentista, somando apenas às limitações já apontadas até aqui de sua ótica teórica.

Por sua vez, Boltho e Weber (2015) elaboram um estudo comparativo com as semelhanças e diferenças das trajetórias de Japão, Coreia, Taiwan e China. Dialogam com diversos autores da literatura do ED mas não se prendem à mesma, visto que operam com o termo "modelo de desenvolvimento do Leste Asiático", munido de outros contornos adicionais. Os principais destes, ao menos para os três primeiros países analisados, seriam: 1) o destaque para o fomento prioritário ao setor manufatureiro, logrado via triangulação de políticas nas dimensões do comércio, indústria e finanças; 2) vislumbre de uma economia externamente competitiva, através de empresas "campeãs nacionais" altamente dinâmicas nos mercados globais; 3) políticas macroeconômicas "adequadas" e "equilibradas", com orçamento sob controle, baixo endividamento e baixa inflação; e, por último, 4) "précondições" políticas e societais, como homogeneidade cultural, alto "capital humano" 
(sinônimo, para os autores, de qualificação educacional de mão de obra) e tecnoburocracias capazes.

A semelhança que destacam como mais saliente em sua análise diz respeito à condução de uma política econômica fiscalmente conservadora (ou ortodoxa) responsável por um orçamento robusto, altas taxas de crescimento, alta poupança conduzindo a investimentos, para além da estabilidade monetária. Esta semelhança entre Japão, Coreia do Sul e Taiwan, contudo, se perde de vista quando enfim analisam a economia política chinesa, visto que a própria dimensão desta última dotou suas empresas de grandes oportunidades para se inserirem em atividades intensivas tanto em capital quanto trabalho (mão de obra), encontrando economias de escala bem superiores vis-à-vis os demais casos (BOLTHO e WEBER, 2015). Mas a maior distinção do caso chinês diz respeito ao legado único do período maoísta. Esse legado se manifesta por dois vetores principais: primeiro, pela preservação de inúmeras instituições políticas do antigo arranjo socialista de planificação central, donde se destaca a própria estrutura do Estado em boa medida. O outro vetor diz respeito ao fato de que, enquanto Coreia do Sul e Taiwan, em determinado ponto, transitaram de uma estratégia de desenvolvimento enfática sobre o setor leve intensivo em trabalho para o pesado intensivo em capital conforme aperfeiçoavam suas vantagens comparativas e competitivas, a China seguiu caminho inverso ante o legado histórico da industrialização sob Mao (lbidem). ${ }^{4}$

Os autores, por fim, comparam tais caminhos de desenvolvimento com destaque para as políticas adotadas, condições da estrutura inicial pré-decolada do crescimento e também resultados, auferidos através dos dados crus dos fundamentos macroeconômicos ex-post. Entretanto, não aprofundaram no estudo das configurações das agências burocráticas responsáveis pelo processo decisório ou sobre o sistema político e padrão representação de interesses junto ao governo. São exitosos em sumarizar detalhes da política industrial chinesa ao passo que deixam de lado elementos institucionais salientados pelos expoentes do ED como Johnson, Amsden e Wade, todos referenciados em sua própria análise (BOLTHO e WEBER, 2017).

\footnotetext{
4 Nogueira (2019) faz uma ótima análise da industrialização pesada maoísta com seu caráter fortemente descentralizado pelo interior, imbricada a considerações estratégico-militares diante da geopolítica da Guerra Fria. Este modelo pautado em clusters manufatureiros puxados pela siderurgia, inclusive, seria o responsável por uma industrialização sem urbanização, fenômeno distinto dos demais países em desenvolvimento.
} 
Lee (2014) é a quarta autora destacada nesta seção que busca interpretar a China à luz do conceito, mas também se afasta do rigor teórico da literatura do ED ao repensar o verbete em termos de efetividade para concretizar políticas públicas e geração de crescimento, novamente mostrando enfoque nos resultados ("outcomes") para matização ex-post. Sua análise envereda por um estudo do aparato governamental, e sua conclusão é que o Estado chinês encontra respaldo em condições atentadas pela literatura cânone desenvolvimentista tais como: órgãos burocrático-decisórios insulados; poucos pontos formais de veto ao policymaking; e compromisso com o desenvolvimento econômico bem como capacidade fiscal e logística do Estado para lográ-lo.

Contudo, há uma grande incógnita, em nosso juízo não desvendada pela autora: como acomodar a aplicação da experiência chinesa ao tipo ideal do ED pelo recorte de tempo das reformas institucionais de Deng em diante ignorando que o processo decisório e burocrático no país passou por ciclos de descentralização e fragmentação ausentes nos demais casos do Leste Asiático. Outra problemática é como denotar exatamente a China visto que o país, em sua ótica, promoveu um padrão de atuação estatal interventor e liberalizante, concomitantemente (LEE, 2014). Elementos como a mercantilização do excedente rural e privatização de algumas estatais coexistiram com o fortalecimento do controle governamental sobre indústrias estratégicas através da política de Jiang Zemin conhecida pelo slogan Grasp the Large, Release the Small ("Agarrem as grandes, soltem as pequenas" ou Zhuādà fàngxiăo - 抓大放小), ampliação em investimentos em setores de alta sofisticação tecnológica, além de um sistema bancário e financeiro majoritariamente público. Por isto, Lee diz que a trajetória chinesa não se encaixa na narrativa de um ED munido de autonomia e insulamento burocrático tampouco numa variante neoliberal; acreditando que estas duas percepções, ao mesmo tempo, dizem respeito a diferentes facetas de uma multifacetada economia política (Ibid.). Novamente, acreditamos que tal problemática constitua falsa questão, visto que, pela manutenção da capacidade de alocação de crédito na economia do país através do sistema bancário hegemonizado pelo governo, bem como pelo domínio dos altos escalões industriais e imersão do Partido Comunista da China (PCCh) na sociedade e no meio empresarial, o Estado tenha permanecido como carro-chefe condutor do processo de desenvolvimento.

Outro a dialogar com os autores seminais debruçados sobre o ED no contexto da Ásia é John Knight (2014). Todavia, é também mais um a se desvencilhar dos 
atributos enfatizados por Johnson e depois por Amsden e Wade: destacando as mudanças que autores subsequentes dentro da mesma literatura desenvolvimentista imprimiram no tipo ideal original, flexibilizando-o, desobriga-se do rigor metodológico em volta do verbete e se debruça mais sobre, de um lado, a estrutura geral de incentivos aos atores políticos e sociais, e, de outro, as políticas econômicas específicas (KNIGHT, 2014).

Pela primeira chave analítica, mostra como as lideranças chinesas a partir de Deng engendraram no desenho do Estado e suas intervenções no regime produtivo um recorte de fato desenvolvimentista, através de três grandes arranjos institucionais diretamente relacionados aos atores políticos e societais. São eles: o sistema estatal de indicações e apontamentos, a ampliação das capacidades fiscais das localidades mediante maior retenção de receitas por estas unidades subnacionais; e, por fim, a ampliação de seus poderes de cooptação dentro do setor público e privado. ${ }^{5} \mathrm{O}$ conjunto de instituições políticas facultando tais estruturas de incentivos reflete o que Knight interpreta por "autoritarismo regionalmente descentralizado", onde o controle e determinação de objetivos e metas se dá pelo governo central e pelo PCCh, mas a efetivação e execução ficaria supostamente a cargo das províncias, cidades e condados. O autor, contudo, não tece qualquer radiografia aprofundada dessa capacidade de execução e implementação de políticas, ou mesmo das prerrogativas quanto às mesmas, por parte dos governos subnacionais/provinciais/locais; e da mesma forma não comenta sobre as consequências após a recentralização fiscal de 1994 (KNIGHT, 2014: p.1340).

Encerrando sua reflexão, destrincha os instrumentos à disposição do governo para concretizar os objetivos do planejamento econômico, observando de modo pertinente que, a despeito de o peso do Estado como porcentagem (\%) do PIB ter caído ao longo do processo de reformas e particularmente na virada da década de 1990 para a de 2000, isto não se deu por qualquer retração de seu papel mas sim pelo dinamismo e florescimento de um setor privado previamente inexistente. Desta forma, Knight (2014: p.1342) traz visão em consonância com Lee (2014) sobre como a autoridade estatal permaneceu pivotal ao processo de acumulação de capital na

\footnotetext{
${ }^{5} \mathrm{O}$ sistema estatal de indicações e apontamentos, definindo trajetórias hierárquicas tanto no que tange ao PCCh quanto no próprio governo, se dava conforme avaliação de desempenho e cumprimento de metas estipuladas pelas autoridades do Estado. Engendrava, desta forma, maior competição entre governos locais e burocratas pela ascensão política enquanto lideranças nacionais. Já a "patronagem" seria factível pela instrumentalização do crédito através dos bancos públicos para criação de relações clientelistas com segmentos importantes do setor estatal e privado (KNIGHT, 2014).
} 
China, mantendo a propriedade sobre os "altos escalões" da economia em setores estratégicos imprescindíveis para guiar investimentos e equacionar gargalos de infraestrutura, como exemplifica bem o reposicionamento do governo através da Grasp the Large, Release the Small.

Fechando a radiografia de autores selecionados, Zhang (2018) e Bolesta (2012) são os mais fiéis, dentre os que vimos até aqui, no estabelecimento de nexos analítico-comparativos entre a literatura desenvolvimentista original e a experiência chinesa, o primeiro apoiado mais sobre o paradigma do ED e seus expoentes-mores e o segundo tanto sobre este último (paradigma) quanto também sobre teóricos mercantilistas pioneiros do desenvolvimentismo, tais como Alexander Hamilton e Friedrich List.

Zhang (2018), por exemplo, mensura se, e em qual medida, a interpretação do ED lança luz sobre a trajetória chinesa. A despeito de confirmar o enquadramento do país às narrativas cânones do paradigma, argumenta que traz novas características (ex: modelo econômico de industrialização planificada aos moldes soviéticos) ausentes nos casos clássicos, tornando imperativa a ampliação da definição em voga do tipo ideal, permitindo frutíferos estudos comparativos com países de transição "pós-socialista" como o Vietnã.

Assim, o autor descobre no caso chinês um Estado extremamente imbricado na sociedade via uma dualidade a qual julga aparentemente contraditória, entre concentração de poder político concomitante a uma relativa descentralização das decisões econômicas, em referência à autonomia usufruída pelas províncias, a qual, assim como Knight, também não explora. Outrossim, destaca que, a partir dos anos 2000, com o governo de Hu Jintao e Wen Jiabao, a perspectiva de desenvolvimento das autoridades chinesas se "horizontalizou" e incorporou agendas adicionais ao "mero" crescimento industrial, como sustentabilidade ambiental e combate às desigualdades (ZHANG, 2018). Dessa forma, está em linha com Lee (2014: p.116), que destaca as preocupações acerca da justiça social, reforço da lei e redução das assimetrias sociais, para além da eficiência econômica como elementos constitutivos de uma "sociedade harmoniosa", principal slogan ideológico do governo Hu/Wen.

Uma última dimensão que Zhang envereda é sobre a rede de agências tanto na burocracia do Estado quanto no partido, conectadas por duas grandes estruturas: o sistema de nomenklatura de apontamentos dentro do PCCh e o sistema administrativo governamental. Aqui, incluso, faz uma contribuição interessante acerca da economia política chinesa em referência a uma das condições 
institucionais de Johnson: a China, em contraposição aos casos do Japão e da Coreia do Sul, jamais teria contado (segundo o autor) com uma agência-piloto aos moldes do MITI ou EPB centralizando a agenda econômica, mas sim uma rede ampla de organismos complementares com distintas atribuições. No partido, com papel supervisor, está o Comitê Permanente do Politburo (CPP), determinando então prioridades e objetivos que as autoridades governamentais no bojo do Conselho de Estado devem seguir, alinhando as políticas de ministérios, governos locais, Banco Central da China, Comissão de Reforma e Desenvolvimento Nacional (“National Development and Reform Comission” - NDRC), etc.

Essa rede relacional entre as agências do PCCh e do Estado chinês, paralelas conforme Zhang, está supostamente inserida numa lógica dual de "concentração política com descentralização da implementação econômica", algo que, segundo ele, constitui o marco possível de governança do país num cenário global onde a política decisória se vê impossibilitada de reeditar o padrão "monocromático" que vigorou nos demais casos desenvolvimentistas clássicos da Ásia (2018: p.21). Embora esteja correto ao destacar como a sinergia Estado-partido ofusca a linha divisória entre ambas as esferas, não aprofunda um detalhamento maior do poder decisório chinês nem na natureza de tal alegada descentralização para outras instâncias, subnacionais ou não. Nesta dimensão, portanto, o autor demonstra uma fragilidade ao confundir as atribuições formais pertinentes à esfera de política econômica (política fiscal a cargo do Ministério das Finanças; política monetária com Banco Central; etc) com a prerrogativa institucional da agência-piloto a cargo da estratégia de desenvolvimento atentada por Johnson. Prerrogativa esta de elencar os setores prioritários à aceleração industrial; e/ou controle, seja direto ou indireto, dos fundos governamentais, alocados conforme as necessidades de cumprimento de tais metas. Zhang não confere, por exemplo, qualquer menção à Comissão para Supervisão e Administração de Ativos Estatais ("State-owned Assets Supervision and Administration Commission" - SASAC), detentora de ativos financeiros dos múltiplos conglomerados estatais e capaz de alavancar grandes blocos de investimentos; sendo por nós destacada na próxima seção.

Concluindo a radiografia dos autores escolhidos da literatura desenvolvimentista aplicada à China, Bolesta (2012) argumenta que, em vários sentidos práticos, o país seguiu o modelo institucional do ED. O fez, entretanto, numa interpretação contrastando as condições históricas vigentes sob o maoísmo em relação ao novo Estado e economia política transicional pós-socialista; contraste 
este somente entendível quando visto comparativamente à luz das adversidades defrontadas pelos países do antigo bloco soviético e nações que também estejam aplicando o receituário desenvolvimentista em suas estratégias de reformas, como seria o caso (segundo ele) de Laos e Vietnã.

Bolesta argumenta que, pela industrialização chinesa sob Mao ter sido menos extensiva vis-à-vis a soviética, com maior incidência da pobreza no meio rural e uma elite manufatureira menos encastelada nas empresas estatais, as reformas transicionais no país encontraram maior flexibilidade e menor oposição política. Além disto, a China contou com um ambiente expansivo de integração econômica e acesso a investimentos e capital, graças: às diásporas chinesas no Sudeste da Ásia distribuídas por Taiwan, Singapura, Hong Kong, Macau, Indonésia, Tailândia, Malásia, etc; à vontade de empresas da Ásia e Ocidente descentralizarem suas cadeias produtivas crescentemente fragmentadas para aproveitar os baixos custos laborais e logísticos (BOLESTA, 2012).

O grande ingrediente de sucesso para aproveitamento de tal contexto expansivo favorável foi a manutenção do alto grau de centralização de capacidades estatais, por sua vez viabilizada graças: à cooptação de dissidências laborais ou conciliação com estas; os vínculos orgânicos com o empresariado nacional e tutela deste, graças a mecanismos diversos de controle aludidos acima como o crédito bancário à iniciativa privada numa lógica pública de financiamento. Foi dessa forma que a China logrou sua via própria de autonomia inserida (BOLESTA, 2012). Em termos de policies (macroeconômicas e institucionais/regulatórias), a China adotou uma estratégia industrial mercantilista antípoda às demais experiências póscomunistas que abraçaram o Consenso de Washington e a ortodoxia econômica, preferindo emular a fórmula clássica dos casos dos ED. Não obstante, destaca que tal política industrialista foi menos coesa do que comumente retratado em análises estilizadas do desenvolvimento chinês, tendo uma série de descontinuidades; de modo que, apenas gradualmente, conformou os predicados e instituições características do tipo ideal, elaborados após um consenso político numa trajetória particular que se deu de forma evolucionária (lbid.).

À guisa de conclusão da presente seção, tendo em vista o apontamento de críticas e incompletudes da gama selecionada de autores e autoras empenhados num arcabouço teórico-intelectual declaradamente desenvolvimentista, a próxima e penúltima - parte do paper objetiva reconstituir a evolução da economia política da China pelo prisma dos quatro requerimentos destacados por Chalmers Johnson 
como imperativos para definir o Estado Desenvolvimentista japonês. A última seção do artigo fecha a análise e traz nossas conclusões, sejam elas pertinentes ao enquadramento, enquadramento parcial ou rejeição do verbete no que diz respeito ao caso nacional do Império do Meio.

\section{A evolução da trajetória de desenvolvimento da China}

Nesta seção reconstituímos a trajetória da economia política chinesa no recorte compreendido entre 1978 e 2008, realizando uma síntese analítica das três primeiras décadas de abertura e transformações de modo a avaliar em que medida seria ou não fiel o enquadramento do caso nacional à tipologia do ED conforme a formulação de Chalmers Johnson. Evidentemente, pelo próprio caráter sintético da reflexão, não será possível dar conta de todos os inúmeros fatos e elementos históricos pertinentes à riquíssima história do país asiático, o que torna nossa reconstituição inevitavelmente seletiva de acordo com o que julgamos de maior relevo para nossa análise.

O ano de 1978 foi tomado como ponto de partida do recorte temporal por ser a partir dele, na $3^{\text {a }}$ reunião plenária do $11^{\circ}$ Congresso do PCCh, que o país anunciaria suas reformas institucionais visando a coexistência entre planejamento, mercado e a sua própria reintegração no sistema econômico interestatal. Visto que o terceiro eixo do ED Johnsoniano prevê métodos discricionários de intervenção estatal na economia em conformidade com o mercado, o período correspondente à Era Mao (1949-1976), por mais analiticamente rico que seja, nada agrega no esforço intelectual aqui proposto. Já 2008 foi escolhido por facilitar um enquadramento exato de 30 anos (aproximadamente a mesma quantidade de tempo que os demais casos clássicos de desenvolvimento do Leste Asiático experimentaram seus catching-ups e ciclos de alto crescimento) e por ser o da eclosão da crise financeira global, cujo epicentro foi o mercado financeiro norte-americano. Desde o episódio, a economia política da China, diante da estagnação mundial, atravessa transformações profundas no regime produtivo em meio à reorientação gradual de um padrão de crescimento puxado pelas exportações para outro voltado ao mercado interno e consumo doméstico (SILVA e MOURA, 2020; PAULA e JABBOUR, 2020). Como estas transformações se encontram ainda em voga, optamos por descartar 0 período que vai de tal episódio em diante.

Por razões óbvias de escopo, esta seção do artigo terá por base a reconstrução dos principais fatos estilizados e mudanças inseridas no curso da Era 
Deng Xiaoping (1978-1992), do governo de Jiang Zemin (1993-2003) e o primeiro mandato do governo Hu Jintao (2003-2008). Será identificada a lógica política da direção conferida às capacidades estatais por cada geração de líderes. Este mapeamento, por vez, é feito com alguns objetos selecionados para análise: a política macroeconômica (fiscal, monetária e cambial); as instituições políticas responsáveis pelo planejamento, execução e supervisão da estratégia industrial; as nuances e reformulações eventuais do sistema político formal; a relação da burocracia decisória com o governo; e também programas e iniciativas de caráter público e nacional ao longo das décadas abarcadas.

Nossa reconstituição histórica, destarte, tem início com a Era Deng. ${ }^{6}$ Inaugurada com o anúncio das reformas institucionais de abertura e reintegração à economia interestatal feito na $3^{\mathrm{a}}$ Reunião Plenária do $11^{\circ}$ Congresso do PCCh, pode ser matizada como um ciclo de experimentação gradual e busca contínua (e conflitiva) pela compatibilização entre planejamento e mercado. Essa qualificação ilustra duas coisas: em primeiro lugar, a dialética que constituiu o principal eixo norteador do debate interno dentro do Partido Comunista (em termos de circunscrição do grau de "liberalização") na década de 1980; e, para além disto, que as reformas chinesas não podem ser tomadas como um todo coeso, tendo diferentes nuances, contradições, disputas internas e ênfases estratégicas conforme cada instante (BLECHER, 2010).

Pela própria importância estratégica das áreas rurais, que em 1978 ainda compreendiam $82,08 \%$ da população chinesa, a contemplação destas tornou-se o objetivo inicial das reformas, cujo primeiro ciclo de inovação institucional facultando a acumulação privada foi com a implementação dos chamados contratos de responsabilidade entre camponeses e o Estado. ${ }^{7}$ Representavam um compromisso de entrega, por parte dos produtores rurais, de parcela de sua produção agrícola ao governo ainda sob preços por este determinados (baixos, principalmente para alimentos e cereais); mas agora também estavam facultados a manter o excedente e comercializá-lo a preços de mercado (BLECHER, 2010; JABBOUR e DANTAS, 2017; JABBOUR e PAULA, 2020).

\footnotetext{
${ }^{6}$ Nos referimos neste artigo à "Era Deng" pelo fato de que, embora Deng Xiaoping jamais tenha ocupado oficialmente as posições de Presidente (cujos postos foram ocupados por Li Xiannian entre 1983-1988 e por Yang Shangkun entre 1988 e 1993) ou Primeiro Ministro (Zhao Ziyang o foi entre 1980 e 1987, depois sucedido por Li Peng entre 1988 e 1998) ao longo da era inicial das reformas, ainda assim era a figura política central e virtual Chefe de Estado da China "de facto"; não "de jure" (MARTI, 2007).

7 Os dados foram retirados do anuário estatístico do país (China Statistical Yearbook) e podem ser conferidos em: http://www.stats.gov.cn/english/statisticaldata/yearlydata/YB1999e/d01e.htm.
} 
Esse redesenho do contrato social e institucional no campo foi o pontapé inicial de profundas transformações no interior da China e da reconfiguração de sua própria divisão social do trabalho, com ampliação concomitante dos preços, da produtividade e da renda agrícolas. A nova estrutura de incentivos, onde os termos de troca não eram mais tão desfavoráveis vis-à-vis o meio urbano, conduziu à forte expansão da produtividade nos primeiros anos das reformas. Concomitantemente, também incrementou a renda retroalimentando o desenvolvimento econômico, ao "criar" tanto a base de acumulação para o surgimento de um mercado doméstico quanto a emergência de inúmeras empresas pequenas e médias produtoras de bens de consumo - "Township and Village Enterprises" (TVEs), derivadas do "empreendedorismo camponês"; visto que agora tais atores sociais também se engajavam em atividades industriais, tendo demanda para fazê-lo (MEDEIROS, 1999; GABRIELE, 2010). ${ }^{8}$ As TVEs, em larga maioria de pequeno e médio porte, constituíram os atores econômico-corporativos mais relevantes da China na década de 1980, sendo os motores iniciais do catching-up e do crescimento no país; contribuindo para a industrialização, geração de empregos e urbanização rural (MEDEIROS, 1999; JABBOUR, 2012).

Essas mudanças denotadas tornaram o consumo interno um dos principais motores do crescimento na primeira fase das reformas institucionais chinesas, com particular força até 1984. Essa industrialização intensiva em trabalho foi factível tanto pela acumulação de capital prévia da Era Mao focada no setor de bens de capital quanto pela observação das vantagens comparativas que o país gozava para iniciar sua inserção exportadora (LO e WU, 2014). Com tal decolada, a China finalmente entraroa numa trajetória de desenvolvimento com mudança estrutural, onde os setores secundário e terciário modernos finalmente ganhariam terreno vis-àvis o primário na composição do emprego e rompendo com o paradigma do período maoísta de industrialização sem urbanização (NAUGHTON, 2007). ${ }^{9}$

O curso das reformas se daria também ao longo do arcabouço da $4^{\text {a }}$ Constituição da RPC, erigida em 1982 e em vigor até os dias de hoje. Embora não tenha rompido paradigmas do ponto de vista da "destruição" ou criação de novas instituições governativas, racionalizou-as conferindo maior regulação legal ao

\footnotetext{
${ }^{8} \mathrm{~A}$ expansão da renda ampliou de forma colossal a demanda por bens de consumo duráveis tais como geladeiras, máquinas de lavar, micro-ondas, televisores, entre outros, justamente o alvo das atividades de muitas TVEs emergentes (MEDEIROS, 1999; JABBOUR e DANTAS, 2017).

${ }^{9}$ De 1978 até 2008 , a participação do setor primário no total da população empregada caiu de $70,5 \%$ para $39,6 \%$, enquanto a do setor secundário e terciário subiram, no mesmo período, de $17,3 \%$ e $12,2 \%$ para $27,2 \%$ e 33,2\%, respectivamente (NATIONAL BUREAU OF STATISTICS, 2020).
} 
processo de escolha dos representantes políticos no país (BLECHER, 2010). Ela separou mais claramente, do ponto de vista formal, as funções dos corpos administrativos e posições de liderança; "fortalecendo" relativamente o governo visà-vis o Partido através da proeminência conferida ao CNP e ao cumprimento da Lei, para além de colocar o Exército sob estrito controle civil. A despeito disto, a nova constituição não foi impeditiva ao contínuo e profundo entrelaçamento entre governo e PCCh; com a estrutura partidária leninista permanecendo incólume como a maior instituição política onde operava o lócus do poder decisório e antecipando as grandes tendências e mudanças que o país veria nas instituições políticas representativas, vide o próprio caso do anúncio das reformas de abertura como vimos e também da reorganização industrial que o país passaria nos anos 1990, como veremos a seguir (lbid.).

Em 1984, o governo iniciou também medidas que deram forma à versão preliminar de seu novo sistema financeiro, com ampla e renovada hegemonia do Estado. O "People's Bank of China" (ou PBOC) foi convertido em Banco Central nacional; concomitantemente à fundação do Industrial and Commercial Bank of China (ICBC) vinculado ao Ministério da Fazenda. Este completaria o conjunto dos chamados "Big Four": os quatro maiores bancos comerciais públicos que concentrariam o crédito no país e atuantes em áreas bem específicas: o ICBC ficaria responsável pelo financiamento às empresas estatais, o Construction Bank of China (CBC) por projetos de investimento, o Agricultural Bank of China (ABC) por inversões na agricultura ou indústria rural e, por fim, o Bank of China $(B O C)$ a cargo do importante gerenciamento de divisas estrangeiras (BRESLIN, 2014; JABBOUR e PAULA, 2020).

O destaque dado até aqui para a nova forma de contratação e organização camponesa e industrialização rural está longe de significar, por outro lado, que a dita "abertura" ao mundo exterior teria sido um fenômeno tardio das mudanças institucionais na China. Desde o anúncio de Deng das "quatro modernizações" em 1978 e prosseguindo pela década de 1980, o país adotou uma estratégia de inserção externa exportadora marcada por um mercantilismo moderno e repaginado (JABBOUR e DANTAS, 2017). Desde o início deste primeiro "estágio" das reformas, já é perceptível uma série de instrumentos diretos e indiretos do Estado fomentando os setores produtivos público e privado nesse sentido: blindagem da competição internacional via quotas de importação em troca de transferência tecnológica, protecionismo tarifário, medidas governamentais de procuração, incentivos à 
pesquisa e desenvolvimento (P\&D), empréstimos preferenciais dos (hegemônicos) bancos públicos, joint ventures com corporações transnacionais proeminentes, etc. (NOLAN, 2013; LO e WU, 2014). Somado a isto, ainda na década de 1980 o governo começou a germinar o que seriam os embriões de sua estratégia econômica nacional de integração via os experimentos das Zonas Econômicas Especiais (ZEEs) na região costeira, em Shantou, Shenzhen, Zhuhai, Xiamen e na província de Hainan (JABBOUR e DANTAS, 2017).

Embora o governo tenha adotado novos arranjos produtivos para equacionar a existência de uma economia de mercado coexistente com outra planificada dentro de seu território, o Estado chinês manteve tanto o sistema político e as instituições responsáveis pela planificação da Era Mao quanto seus planos quinquenais como eixos norteadores das metas e critérios gerais da estratégia de desenvolvimento (BLECHER, 2010). Estas instituições eram as seguintes: a Comissão de Planejamento Estatal ("State Planning Commission" ou SPC), estabelecida pela Constituição de 1954 com a missão de elaborar os planos quinquenais (PQs) e metas de longo prazo; e a Comissão Econômica Estatal ("State Economic Commission" ou SEC), que buscava ajustar a implementação dos PQs para a lógica dos anos individuais e para os segmentos produtivos específicos (DONNITHORNE, 1964).

Ambas as comissões eram diretamente subordinadas ao Conselho de Estado; e permaneceram fulcrais na China pós-reformas, a despeito de atravessarem reorganizações na década de 1990. Com a abertura, tais instituições tiveram suas missões ligeiramente redesenhadas: a SPC permanecia a cargo do planejamento plurianual, embora agora pudesse também estabelecer medidas de macro-controle e intervenção governamental em suporte de indústrias pilares e promover novos segmentos estratégicos; enquanto a SEC buscava estabelecer grandes grupos empresariais e associações quase-regulatórias permitindo ao governo acompanhalos indiretamente (HEILMANN e SHIH, 2013).

Acerca do sistema político chinês, dedicamos este parágrafo e os dois próximos a uma breve síntese de seu funcionamento para fornecer um entendimento melhor da complexidade do país em termos de poder decisório. Tal sistema, unitário embora fragmentado, se manteve relativamente incólume desde a Era Mao; tendo sobrevivido tanto a episódios turbulentos como a Revolução Cultural quanto à $2^{\underline{a}}$ e 3a Constituições da RPC (de 1975 e 1978, respectivamente), que esvaziaram 
parcialmente a legitimidade e poder de decisão das instituições do Estado ao colocar explicitamente o PCCh acima das mesmas (BLECHER, 2010).

O sistema político e representativo formal da China, diferentemente dos correspondentes ocidentais, não prevê uma clara separação de poderes; e sua instituição nuclear mais poderosa é o Congresso Nacional do Povo ou CNP, por sua prerrogativa de nomeação direta da: Presidência da RPC; da Comissão Militar, da Suprema Corte Popular e, mais importante, do próprio Conselho de Estado (SAICH, 2015). O CNP tem seu quadro de representantes eleito indiretamente pelos Congressos Provinciais do Povo (principais instâncias legislativas subnacionais), que por vez tem seus membros também escolhidos indiretamente pelos Congressos dos Condados e Cidades, instâncias mais baixas da estrutura política chinesa e estas sim com eleição direta (BLECHER, 2010; SAICH, 2015).

O Conselho de Estado, por vez, chefiado pelo Primeiro-Ministro, seu vice, inúmeros conselheiros e também seu secretariado geral, é a mais alta instância administrativa da China; e a tal respondem tanto os diferentes ministérios do país quanto $\circ \mathrm{PBoC}$, os órgãos de planificação previamente citados e também as ramificações executivas dos governos locais $(\mathrm{SAICH}, 2015)$. Contudo, é precipitado apontar o Conselho como o Poder Executivo do país, pois a própria Constituição da RPC jamais o matiza enquanto tal e lhe impede de questionar os méritos das decisões tomadas no bojo do CNP, ao qual é subordinado. Destarte, seria mais acurado, assim como a Constituição chinesa define, apontá-lo como "corpo executivo do mais alto órgão do poder estatal" (JIANG, 2003: p.128, tradução própria). Evidentemente, cabe ao Conselho de Estado de forma direta, tal como também apontado pelo Artigo 89 da Constituição de 1982, a formulação e implementação - com os órgãos citados (SPC e SEC) e seus distintos Ministérios nas áreas correspondentes - dos planos nacionais de desenvolvimento, regulações e a definição da alocação de recursos do orçamento governamental. Contudo, estes (planos e orçamento) devem sempre ser responsivos e contemplar áreas prioritárias e anseios incrustados nas diretrizes mais gerais antes passadas pelo CNP. E, mesmo que o Conselho escolha os quadros compondo seus ministérios, departamentos e instituições administrativas, todos devem ser chancelados/referendados pelo Congresso nacional e por este podem ser demovidos (JIANG, 2003).

Em suma, por tudo que vimos até então, a Era Deng pode ser considerada a primeira fase das reformas, não numa perspectiva etapista ou teleológica, mas por 
denotar diferentes ênfases, concertações políticas e experimentações institucionais. Estas, embora tenham dado o pontapé inicial à decolada econômica da República Popular e sua inserção internacional, sofreram transformações qualitativas e descontinuidades em diversos aspectos. O câmbio da primeira à segunda fase, ganhando contornos mais claros e definitivos no governo Jiang Zemin, denotaria por vez uma recentralização considerável das capacidades estatais, para além da transição de uma industrialização intensiva em trabalho $(L)$ para outra gradualmente mais intensiva em tecnologias, revelando também um aprofundamento e maior proporção na relação capital (K) - produto na economia chinesa (LO e WU, 2014).

Passando agora ao governo Jiang, iniciando em 1993, este é bastante relevante para a análise deste paper por ser nele onde se dá a recentralização das capacidades fiscais na esfera nacional; concomitantemente a, a partir da segunda metade da década, uma paradigmática reorganização das atividades e papéis do Estado e do setor privado, reorganização esta consistindo no segundo grande ciclo de inovação institucional pós-reformas, conferindo proeminente rol aos novos e fortalecidos conglomerados públicos (JABBOUR e PAULA, 2020).

$O$ pontapé inicial, antes mesmo da nova estratégia industrialista, foi a reorganização da SEC ainda em 1993. A mesma foi reformulada enquanto Comissão Estatal de Economia e Comércio ("State Economic and Trade Commission", ou SETC), e absorveria alguns ministérios como do carvão, da metalurgia e da indústria de maquinários, convertendo-os em escritórios com jurisdição para formulação de políticas e arcabouços institucionais específicos para esses determinados segmentos da indústria (HEILMANN e SHIH, 2013; SAICH, 2015).

No ano seguinte (1994), em turno, seria engendrada uma importante recentralização fiscal na esfera nacional de governo, através de um novo sistema de compartilhamento e atribuições tributárias (NAUGHTON, 2007; GABRIELE, 2010). Essa recentralização fiscal veio acompanhada, por sua vez, da profunda e importante reestruturação institucional do sistema bancário nacional que também era posta em prática. Ela começou ainda em 1994 com a criação dos três colossais "bancos de política", que seriam os novos braços financeiros do Estado no fomento ao investimento e canalização seletiva de recursos à atividade produtiva: o Agricultural Development Bank of China, o China Development Bank e o Ex-Im Bank of China; o primeiro sob jurisdição do banco central do país e os dois últimos respondendo também ao Conselho de Estado. Dando prosseguimento a essas 
reformas, em fins de 1998 o governo rearranjou a estrutura organizacional do banco central de modo a abolir as ramificações específicas das províncias e estabelecer novas de caráter mais macro-regional. Visava-se, desta forma, mitigar influências centrípetas sobre a determinação da política monetária (NAUGHTON, 2007). Todas essas transformações elencadas fariam com que, desde a década de 1990, os bancos concentrassem cifra superior a $80 \%$ do financiamento total às empresas no país (BRESLIN, 2014).

Em 1998, o outro e mais relevante órgão de planificação (responsável por elaborar os PQs do governo) também passaria por mudanças: a SPC seria rebatizada como Comissão Estatal de Planejamento do Desenvolvimento ("State Development Planning Commission" ou SDPC), embora sem novas ou menos atribuições. Esta reformulação se deu no bojo de uma grande recentralização e "revolução institucional" anunciada no 9o CNP realizado em março de 1998, visando fundir ministérios, agências, departamentos (ao passo que extinguia outros) de modo a criar um sistema administrativo mais eficiente e integrado para o Estado chinês (SAICH, 2015) $\cdot{ }^{10}$ Esta recentralização da organização estatal, que sucedeu a fiscal de 1994, seria prelúdio da última recentralização que o país assistiria na década, desta vez no seio da estrutura da indústria, como será visto abaixo.

Definitivamente, a transformação mais importante engendrada pelo governo Jiang foi a do redesenho industrial através do já mencionado programa "Grasp the Large, Release the Small', compondo a verdadeira política chinesa dos campeões nacionais (NOLAN, 2013). Declarado oficialmente na 4⿳亠口冋 Seção Plenária do Comitê Central do PCCh em 1999, em parte de forma responsiva aos efeitos da crise financeira regional asiática de dois anos antes, visava uma grande reformulação corporativa onde as firmas estatais de menor porte seriam incorporadas às maiores ou vendidas à iniciativa privada (LO e WU, 2014; JABBOUR e PAULA, 2020). Através do mesmo, o Estado reposicionou sua atuação consolidando mais de 140 grandes e modernos conglomerados públicos onde era acionista majoritário, e que dominam os nichos estratégicos de seu regime produtivo até hoje, com destaque aos seguintes: aço/siderurgia (BaoSteel; WuSteel; AnSteel; Hebei Steel Group; Shandong Steel Group); automobilístico (Great Wall Motors; Shanghai Automobile Industrial Group; Yiqi; Dongfeng); construção civil e infraestrutura (China State

${ }^{10}$ Como resultado, os 44 departamentos existentes sob o Conselho de Estado seriam reduzidos para 29 ministérios, comissões, administrações e bancos. 
Construction; China Rail Construction); etc (NOLAN, 2013; LO e WU, 2014; JABBOUR e PAULA, 2020).

Desde o início das reformas em 1978 até tal reorganização da estrutura industrial estatal em 1998, se deu um declínio contínuo da contribuição das empresas estatais ("State Owned Enterprises" ou SOEs) com relação ao PIB de colossais $78 \%$ para $32 \%$. Contudo, após tal ano e mudança institucional paradigmática, essa participação das SOEs se estabilizou em torno da cifra de aproximadamente 35\% pelo restante dos anos 2000 (LO e WU, 2014). Tal manutenção de um patamar ainda bastante elevado pós-1998 condiz justamente com a centralização e renovada ênfase sobre as firmas dos conglomerados públicos, compreendendo indústrias de maior escala e mais intensivas em capitais; com esta última característica explicando em parte a razão de, mesmo mantendo seu peso com relação ao PIB, as SOEs terem declinado constante e ininterruptamente em termos de participação no emprego nacional (GABRIELE, 2010; LO e WU, 2014). ${ }^{11}$

Por fim, a cereja do bolo da reorganização da estratégia industrialista no governo Jiang viria com a criação da antes mencionada SASAC em 2002. Esta viria para ocupar as funções antes realizadas pela SETC, abolida em 2003 após brevíssima incorporação ao também recém-criado Ministério do Comércio (MOFCOM). Ao passo que a SASAC gerenciava "apenas" os conglomerados públicos ou empresas onde o Estado fosse o acionista majoritário, as demais atribuições da SETC que implicassem em marcos regulatórios ou arcabouços institucionais para setores da indústria ou firmas privadas foram redistribuídas entre os demais ministérios do governo chinês (SAICH, 2015). Para além disto, o órgão (SASAC) também ficaria responsável pelos interesses acionistas do governo central nas decisões de tais grupos empresariais, para além de atuar como facilitador e promotor da implementação efetiva das reformas econômicas (GABRIELE, 2010; JABBOUR e PAULA, 2020). ${ }^{12}$

\footnotetext{
11 De 1998 até 2008, a parcela de pessoas empregadas nas firmas eminentemente estatais (SOEs, excluindo da conta por exemplo empresas de propriedade coletiva) sobre o total declina de $12,82 \%$ para 8,32\% (NATIONAL BUREAU OF STATISTICS, 2015).

12 É válido frisar que mesmo as firmas nominalmente privadas também possuiriam inúmeras conexões com o setor público via uma gama de elos em termos de propriedade e financiamento, em extensão muito superior às suas contrapartes nos demais países capitalistas. Gabriele cita, por exemplo, os próprios casos da Haier e da Legend. Embora ambas sejam privadamente administradas, a primeira é controlada pelo escritório da SASAC da cidade de Qingdao e a segunda possui como acionista majoritário a Academia Chinesa de Ciências, atrelada diretamente ao Conselho de Estado (2010: p.330).
} 
O governo do presidente Hu Jintao e do Primeiro Ministro Wen Jiabao, assumindo na esteira de tal recentralização das capacidades estatais, foi por vez o responsável por reforçar as tendências prévias acerca da nova estratégia de desenvolvimento (HEILMANN e SHIH, 2013). Esse reforço é visto através de um esforço final de "institutional-building", corroborado pela criação, em março de 2003 enquanto um dos seus primeiros marcos, da poderosa Comissão Nacional de Desenvolvimento e Reforma ("National Development and Reform Commission” ou $\mathrm{NDRC}$ ) em substituição à SDPC. A NDRC, vigente até hoje, e que permaneceu (assim como a SASAC) insulada sob égide direta do Conselho de Estado, único organismo ao qual é responsiva, herdou todas as funções de planejamento e elaboração de programas de desenvolvimento industrial da comissão anterior, agora empoderada também com atribuições sobre questões tais como planejamento familiar, energia e produção de grãos (HEILMANN e SHIH, 2013; SAICH, 2015). ${ }^{13}$

Ao mesmo tempo, também adotaria programas que ajudariam a inserir a China na próxima fase de sua estratégia de catching-up, voltada ao adensamento tecnológico. Conforme Chen e Naughton (2013), o governo Hu/Wen teve como pilares da estratégia industrial dois grandes programas em particular: o primeiro consistiu nos chamados dezesseis (16) megaprojetos lançados oficialmente no biênio 2005-2006 com o "Programa de Médio e Longo Prazo de Ciência \& Tecnologia" (aqui resumido como MLP); enquanto o segundo foi o "Programa de Fomento às Indústrias Estratégicas Emergentes" (Strategic Emerging Industries ou SEI), adotado em 2010 enquanto resposta aos efeitos adversos da crise financeira global e, exatamente por isto, deixado de lado nesta reflexão em função de nosso recorte temporal.

Os megaprojetos aludidos no primeiro programa podem ser, ao menos em parte, contextualizados em meio às condições políticas norteando a ascensão de Hu à liderança da China. Integrava um grupo interno do PCCh alternativo ao dos predecessores; e, embora viesse a deter a posição mais alta na hierarquia governamental, não gozava de apoio majoritário e inconteste entre os militares tampouco no Comitê Permanente do Politburo, onde os aliados de Jiang Zemin perfaziam 6 dos 9 membros (FEWSMITH, 2003). Buscou (junto com Wen) portanto, em tal cenário, imprimir com bastante cautela e gradualismo sua marca distintiva e também novas ênfases sobre as políticas e medidas de Jiang e Zhu, sem repudiá-

13 A lista completa de atribuições da NDRC pode ser conferida no seguinte link: https://en.ndrc.gov.cn/mfndrc 8237/200812/t20081217 1193980.html. 
las (CHEN e NAUGHTON, 2013). Esta marca, denotando em parte uma continuidade de caminho institucional, foi materializada enfim com o documento intitulado "Perspectiva Científica do Desenvolvimento" (Scientific Outlook on Development ou Kēxué Fāzhăn Guān - 科学发展观), sumarizando o discurso de Hu no seio da $3^{a}$ Reunião Plenária do $16^{\circ}$ Congresso do Partido Comunista em outubro de 2003. ${ }^{14}$ Embora amplo, o documento detém, do ponto de vista da referência à estratégia industrial, uma forte ênfase acerca da necessidade de criar um ambiente fértil à inovação endógena nacional com políticas de fomento à transferência e adensamento de tecnologias nas cadeias produtivas (CHEN e NAUGHTON, 2013; LO e WU, 2014).

O MLP saiu da retórica partidária para a governamental oficial a partir do $1^{\circ}$ Pleno do novo Conselho do Estado reunido em 22 de março de 2003, quando começou a ser rascunhado com frequentes consultas a diversos setores do governo, do setor privado e de outros segmentos da sociedade. ${ }^{15}$ A compilação do plano formal em suas diretrizes gerais ficava a cargo do Ministério da Ciência e Tecnologia, mas o processo culminando até tal ponto envolvia outros dois atores institucionais relevantes: a NDRC e o Ministério das Finanças, a primeira envolvida com a adequação e complementaridade dos projetos com a política industrial e o segundo pela política fiscal e orçamentária viabilizando-os (CHEN e NAUGHTON, 2013). O MLP buscava intensificar a inserção chinesa nos estágios de maior valor agregado das cadeias produtivas e em setores mais nevrálgicos à $3^{\text {a }}$ Revolução Industrial (ex: componentes eletrônicos), ao mesmo tempo em que buscava salvaguardar indústrias chaves do país justificadas tanto pela capacidade de canalização dos investimentos (como aviação e construção civil) quanto relacionadas à segurança energética como petróleo e nuclear. Exatamente por isto, o Estado foi também um dos maiores beneficiários de tal programa através dos conglomerados públicos que executavam ou supervisionavam seus diversos projetos, embora a iniciativa privada também tenha sido favorecida com a comercialização de tecnologias recém descobertas enquanto spin-offs (Ibid.: p.16).

\footnotetext{
$14 \mathrm{O}$ discurso de $\mathrm{Hu}$ Jintao pode ser conferido na íntegra em: http://en.people.cn/102774/8024779.html.

15 Chen e Naughton (2013: p.13-4) identificam pelo menos três grandes grupos consultados pelo governo. O primeiro compreendia o grupo pioneiro na criação do primeiro sistema de pesquisa científica nacional ainda nos anos 1950, responsável por grandes sofisticações tecnológicas nas áreas nuclear e de mísseis balísticos. O segundo grupo trazia mais de 1000 cientistas e engenheiros de todo o país que se envolveram diretamente na escrita e avaliação do primeiro rascunho do plano em Beijing. O terceiro grupo, por fim, incluía desde sugestões coletadas de fóruns e conferências internos do partido até de analistas proeminentes, como Justin Yifu Lin e Hu Angang.
} 
Ante toda a estrutura narrada nesta seção, partimos agora à conclusão deste artigo onde, enfim e com base na genealogia tecida, apontamos o enquadramento ou não aos predicados johnsonianos já pontuados.

\section{Considerações Finais}

Após a reconstituição histórica estilizada da economia política chinesa feita na seção anterior, agora finalmente procedemos à análise acerca da aplicabilidade ou não do caso da RPC aos predicados do Estado Desenvolvimentista. O faremos inicialmente mostrando o quadro 1 abaixo com os quatro pontos da tipologia e o apontamento se a comparação é procedente, improcedente, parcialmente procedente e as razões para cada resposta logo em seguida. Quando necessário, também iremos fazer alguns paralelos com as demais experiências de industrialização tardia dos outros casos de ED do Leste Asiático.

Quadro 1- Enquadramento das Características do Estado Desenvolvimentista à China

\begin{tabular}{|l|l|c|c|}
\hline 1 & $\begin{array}{l}\text { Existência de uma elite burocrática competente, não } \\
\text { perdulária e relativamente pequena, responsável pelo } \\
\text { apontamento de indústrias estratégicas a serem } \\
\text { desenvolvidas, determinação dos meios para fazê-lo e } \\
\text { supervisão da execução do planejamento. }\end{array}$ & $\begin{array}{c}\text { Enquadramento } \\
\text { parcial }\end{array}$ \\
\hline 2 & $\begin{array}{l}\text { Sistema político que não imponha restrições ou vetos à } \\
\text { agenda da burocracia decisória. }\end{array}$ & $\begin{array}{l}\text { Enquadramento } \\
\text { parcial }\end{array}$ \\
\hline 3 & $\begin{array}{l}\text { Intervenção estatal discricionária na esfera econômica. } \\
\text { total }\end{array}$ & $\begin{array}{l}\text { Enquadramento } \\
\text { tonento }\end{array}$ \\
\hline 4 & $\begin{array}{l}\text { Agência-piloto governamental concentrando poder e enquadramento } \\
\text { autonomia para determinação dos planos de } \\
\text { desenvolvimento, sua consecução e supervisão. }\end{array}$ & $\begin{array}{c}\text { Enquala } \\
\text { total }\end{array}$ \\
\hline
\end{tabular}

O apontamento de um enquadramento parcial com relação ao primeiro predicado pode parecer, a princípio, curioso. Embora não reste dúvidas acerca da competência das autoridades chinesas, principalmente à frente dos órgãos de planejamento econômico, para estipulação de objetivos estratégicos e dos meios para lográ-los, esta não constitui exatamente uma "burocracia"; muito menos uma "burocracia weberiana" tal como aparece nas narrativas de Johnson para o Japão ou Amsden para a Coreia do Sul. No caso japonês, mesmo com o presidente indicando - geralmente - políticos para assumirem os ministérios governamentais, o restante da composição ministerial, incluindo os vice-ministros, era majoritariamente composta de burocratas de carreira. O MITI, por exemplo, chegou a deter 36 conselhos deliberativos integrados em larga maioria por burocratas e civis 
especialistas em diferentes áreas discutindo medidas e legislações para a política industrial (JOHNSON, 1982). ${ }^{16}$ No caso sul-coreano, embora os altos escalões do EPB fossem apontados diretamente pelo presidente, a imensa maioria de seus quadros era recrutada mediante o Sistema Haengsi (Exame de Alto Serviço Civil), bastante rigoroso e que deu forma a uma tecnoburocracia altamente qualificada e no geral oriunda das elites letradas do país que haviam estudado na Universidade Nacional de Seoul (KIM, 1992).

$\mathrm{Na}$ realidade chinesa, como vimos na Seção 4, não é a burocracia a desempenhar tal papel. Começando com a Comissão de Planejamento Estatal ("State Planning Commission" - SPC) até 1998, passando pela breve Comissão Estatal de Planejamento do Desenvolvimento ("State Development Planning Commission" - SDPC) entre 1998 e 2003, e finalmente chegando até a Comissão Nacional de Desenvolvimento e Reforma ("National Development and Reform Commission" ou NDRC) em vigor até hoje, a planificação econômica sempre foi elaborada e executada por quadros políticos. A imensa maioria dos oficiais destes órgãos era indicada pelo Conselho de Estado e referendada pelo CNP, sendo composta de quadros filiados ao PCCh e com trajetórias político-administrativas prévias. Com isto, não queremos afirmar que os mesmos (quadros a cargo da SPC, SPDC ou NDRC) não possuem expertise ou formação para desempenhar tais funções, mas somente destacar que não são burocratas de carreira. Tampouco atribuímos aqui caráter valorativo à formação política desses integrantes, visto que a dimensão política, em nossa concepção, está sempre imbricada à economia e ao mundo material enquanto epifenômeno da produção e da distribuição material. Apenas frisamos, portanto, que a experiência chinesa neste item específico não fornece um encaixe integralmente acurado ao ponto tal como postulado por Johnson.

Com relação ao segundo item, também consideramos que há um enquadramento parcial. Embora jamais tenhamos encontrado, no bojo da literatura acerca da economia política chinesa que já tivemos acesso, quaisquer alusões à instância do Legislativo ou do Judiciário interferindo direta ou indiretamente na

\footnotetext{
${ }^{16}$ Evidentemente, estes fatos por si só não corroboram um isolamento dos quadros burocráticos na formulação da estratégia de desenvolvimento, muito menos a inexistência de influência da classe política e empresarial. Como o próprio Johnson (1982) documenta, o primeiro ministro do MITI Inagaki Heitaro, por exemplo, era um industrialista representante da antiga zaibatsu Furukawa; e 14 dos 15 vice-ministros de tal órgão entre 1949 e 1976, ao se aposentarem, foram empregados pelos grandes conglomerados empresariais das Keiretsus, após terem sido por eles auxiliados com políticas ou arranjos institucionais favoráveis. Essa ligação é denominada de Amakudari (天下り - “Descida do Céu”).
} 
agenda econômica do governo ou em sua estratégia nacional de desenvolvimento, é inegável que as linhas seguidas pelos órgãos de planejamento sob a tutela do Conselho de Estado refletem, em algum grau, as predileções derivadas das concertações de forças do CNP. Fazemos esta ressalva, é claro, cientes também da complexidade do sistema político da China e da turva separação entre poderes no país (JIANG, 2003).

Sobre o papel do intervencionismo do Estado sobre a economia da China, é apenas com o governo Jiang Zemin, com a criação de novas instituições, recentralização das capacidades estatais e outras medidas corroborando a acentuação da inserção exportadora e manufatureira, que a estratégia nacional de desenvolvimento da China passa a se assemelhar mais ao cardápio de políticas e instituições dos demais EDs do Leste Asiático, resguardadas é claro algumas diferenças remanescentes. As estruturas empresariais oligopolistas formadas na economia política chinesa, por exemplo, são idênticas às utilizadas no Japão com as keiretsus ou na Coreia com as chaebols, mas a RPC guarda o diferencial da maioria de tais atores corporativos serem empresas públicas, endossando, portanto, um poder e influência discricionária ainda maior do governo sobre a atividade econômica.

No que tange ao terceiro ponto, portanto, há uma total corroboração a partir da existência de métodos de intervenção estatal em conformidade com uma economia de mercado, com a China fazendo uso de um conjunto de policies que também se viram presentes nos casos clássicos de Japão, Coreia do Sul e Taiwan, embora nuances também existam tais como a citada na estrutura de propriedade da maior parte das empresas. Estas diferenças, contudo, em nossa avaliação, apenas conferem maior riqueza e particularidade analítica aos estudos sobre a economia política chinesa ou comparativos de forma geral.

Acerca do quarto e último ponto, também consideramos que há um enquadramento total. Não obstante as mudanças de nome entre os anos 1990 e os 2000, tanto a SPC quanto a SPDC e a NDRC podem sim ser comparadas ao MITI e ao EPB em termos de elaboração das diretrizes gerais da estratégia de desenvolvimento através dos planos quinquenais, mostrando as prioridades das autoridades políticas incumbentes no Estado acerca do curso produtivo futuro. $O$ fato de contarem com outras instituições - como a SEC, a SETC e a SASAC enquanto executoras de tal planejamento ou adaptando os PQs a nível micro não é impeditivo à equivalência, pois, mesmo nos casos japonês e sul-coreano, o MITI e o 
EPB também contaram com ajuda de ministérios e outras instituições (burocráticas, financeiras, etc) para formatarem seus planos a nível setorial ou para detalhamento institucional maior (JOHNSON, 1982; KIM, 2011)

À guisa de conclusão, esperamos que esta reconstituição da trajetória do Império do Meio tenha oferecido ao leitor perspectivas interessantes acerca do país e servido de estímulo para futuros estudos. Como frisamos alhures neste mesmo paper, tentamos nos ater, via um prisma institucionalista, somente aos fatos e acontecimentos julgados mais relevantes por nós para a reflexão proposta acerca da estratégia nacional de desenvolvimento. Evidentemente, não temos a pretensão de afirmar que este artigo "esgotou" todos os fenômenos e dimensões da China: estudos futuros podem encontrar considerações finais distintas ainda que partam do mesmo arcabouço teórico. A não-adequação (ou adequação parcial) do caso chinês ao tipo ideal do ED, tal como definido em termos rígidos e seminais por Chalmers Johnson nos anos 1980, não é um resultado desanimador, mas sim atestado da complexidade e riqueza analítica do país asiático, riqueza esta que nos fará continuar estudando tal caso em nossas agendas futuras de pesquisa.

\section{REFERÊNCIAS}

AMSDEN, A. Asia's Next Giant: South Korea and Late Industrialization, New York: Oxford University Press, 1989.

BLECHER, M. China against the Tides: Restructuring through Revolution, Radicalism and Reform. 3. Ed. New York: Continuum, 2010.

BOLESTA, A. China as a Post-Socialist Developmental State: Explaining Chinese Development Trajectory. Tese de Doutorado apresentada na London School of Economics and Political Science, 2012.

BOLTHO, A; WEBER, M. "Did China follow the East Asian Development Model?". In NAUGHTON, B.; TSAI, K. (eds.). State Capitalism, Institutional Adaptation and the Chinese Miracle. New York: Cambridge University Press, 2015.

BRESLIN, S. Financial transitions in the PRC: banking on the state?. Third World Quarterly, v. 35, n. 6, p.996-1013, 2014.

CHANG, H-J. The East Asian Development Experience: The Miracle, the Crisis and the Future. London: Zed Books, 2006.

CHEN, L.; NAUGHTON, B. The Emergence of Chinese Techno-Industrial Policy: From Megaprojects to Strategic Emerging Industries, 2003-2011. Janeiro de 2013: http://inctpped.ie.ufri.br/spiderweb/pdf/Chen Ling and Barry Naughton.pdf. Access in 16/08/2020.

DONNITHORNE, Audrey. China's Economic Planning and Industry. The China Quarterly, n.17, p.111-124, 1964.

EVANS, P. O Estado como problema e solução. Lua Nova, v. 28, p.107-156, 1993.

FALLOWS, J. Looking at the Sun: The Rise of the New East Asian Economic and Political System. New York: Vintage Books, 1994. 
GABRIELE, A. The Role of the State in China's Industrial Development: A Reassessment. Comparative Economic Studies, v.52, p.324-350, 2010.

GORE, C. Methodological nationalism and the misunderstanding of the East Asian industrialisation. The European Journal of Development Research, v.8, n.1, p.77-122, 1996.

HARVEY, D. A Brief History of Neoliberalism. New York: Oxford University Press, 2005.

HEILMANN, S; SHIH, L. The Rise of Industrial Policy in China, 1978-2012. HarvardYenching Institute Working Paper Series, p.1-23, 2013.

HSIEH, C-T.; SONG, Z. Grasp the Large, Let Go Of the Small: The Transformation of the State Sector in China. NBER Working Paper Series, n.21006, p.1-27, 2015.

JABBOUR, E. China Hoje: Projeto Nacional, Desenvolvimento e Socialismo de Mercado. São Paulo: Anita Garibaldi, 2012.

JABBOUR, E; DANTAS, A. The political economy of reforms and the present Chinese transition. Brazilian Journal of Political Economy, v.37, n.4, p.789-807, 2017.

JABBOUR, E.; PAULA, L. F.. Socialization of Investment and Institutional Changes in China: A Heterodoxy Approach. Forum for Social Economics, v.49, p.1-14, 2020.

JIANG, J. The National People's Congress of China. Beijing: Foreign Languages Press, 2003.

JOHNSON, C. MITI and the Japanese Miracle: The Growth of Industrial Policy, 1925-1975. California: Stanford University Press, 1982.

KIM, B-K. Economic Policy and Economic Planning Board (EPB) in Korea. Asian Affairs, v.18, n.4, p.197-213, 1992.

KIM, B-K. "The Leviathan: Economic Bureaucracy under Park". In KIM, B-K; VOGEL, E. (eds.). The Park Chung-Hee Era: The Transformation of South Korea. London: Harvard University Press, 2011.

KNIGHT, J. China as a Developmental State. The World Economy, v.37, n.10, p.13351347, 2014.

LEE, C-K. "The Chinese Developmental State: Miracle or Mirage?". In WILLIAMS, M. (ed.). The End of the Developmental State?. London: Routledge, 2014.

LI, R. "Changing Developmental-ness of the State - The Case of China". In CHU, Y-W. (ed.). The Asian Developmental State: Reexaminations and New Departures. London: Palgrave Macmillan, 2017.

LIN, J. Y.; FANG, C.; ZHOU, L. China's Economic Reforms: Pointers for Other Economies in Transition?. Policy Research Working Paper (World Bank), n.1310, p.1-41, 1994.

LO, D.; WU, M. "The State and industrial policy in Chinese economic development". In KOZUL-WRIGHT, R.; SALAZAR, J.; NUBLER, I. (eds.). Transforming Economies: Making industrial policy work for growth, jobs and development. Genebra: International Labour Organization, 2014.

MARTI, M. A China de Deng Xiaoping: O homem que pôs a China na cena do Século XXI. Rio de Janeiro: Nova Fronteira: 2007.

MEDEIROS, C. Economia e Política do Desenvolvimento Recente na China. Revista de Economia Política, v.19, n.3, p.93-112, 1999.

NAUGHTON, B. The Chinese Economy: Transitions and Growth. London: The MIT Press, 2007.

NATIONAL BUREAU OF STATISTICS. China Statistical Yearbook 2015: http://www.stats.gov.cn/tjsj/ndsj/2015/indexeh.htm >. Access in 28/09/2020. 
NOGUEIRA, I. Acumulação, Distribuição e Estratégia sob Mao: Legados do maoísmo para o desenvolvimento da China. Carta Internacional, v.14, n.2, p.27-51, 2019.

NOGUEIRA, I.; HAO, Q. State and Capitalist Class in China's Economic Transition: From Great Compromise to Strained Alliance. Political Economy Research Institute Working Paper, n.467, p.1-29, 2018.

NOLAN, P. Re-balancing China: Essays on the Global Financial Crisis: Industrial Policy and International Relations. London: Anthem Press, 2013.

PAULA, L.F.; JABBOUR. E. The Chinese Catching-Up: A Developmentalist Approach. Journal of Economic Issues, v.54, n.3, p. 855-875, 2020.

REINERT, E. Como os países ricos ficaram ricos...e por que os países pobres continuam pobres. Rio de Janeiro: Contraponto, 2016.

REPUBLIC OF CHINA. National Statistics - Table: Principal Figures - Annual: http://statdb.dgbas.gov.tw/pxweb/Dialog/varval.asp?ma=NA8101A1A\&ti=Principal\%20Figure s-Annual\&path=../PXfileE/Nationallncome/\&lang=1\&strList=L. Access in 20/08/2020.

SAICH, T. Governance and Politics of China. 4. Ed. London: Palgrave, 2015.

SILVA, R.; MOURA, R. Redesign or Demise of Old Developmental States? East Asia in the 2008 Post-Financial Crisis. Brazilian Journal of Political Economy, v.40, n.4, p.689-711, 2020.

WADE, R. Governing the Market: Economic Theory and the Role of Government in East Asian Industrialization. Princeton: Princeton University Press, 1990.

WEAVER, K.; ROCKMAN, B. "When and How Do Institutions Matter?". In WEAVER, K.; ROCKMAN, B. (eds.). Do Institutions Matter? Government Capabilities in the United States and Abroad. Washington, DC: Brookins Institutions Press, 1993.

WORLD BANK. World Indicators: http://databank.worldbank.org/data/reports.aspx?source=world-development-indicators.

Access in 02/01/2020.

YEUNG, H. W. Strategic Coupling: East Asian Industrial Transformation in the New Global Economy. Ithaca: Cornell University Press, 2016.

ZHANG, F. The Chinese developmental state: standard accounts and new characteristics. Journal of International Relations and Development, n.21, p.739-768, 2018.

\section{NOTAS DE AUTOR}

\section{CONTRIBUIÇÃO DE AUTORIA}

Luiz Fernando de Paula - Concepção. Coleta de dados, Análise de dados, Elaboração do manuscrito, revisão e aprovação da versão final do trabalho

Rafael Moura - Concepção e elaboração do manuscrito. Coleta de dados Participação ativa da discussão dos resultados; Revisão e aprovação da versão final do trabalho.

\section{FINANCIAMENTO}

Não se aplica.

CONSENTIMENTO DE USO DE IMAGEM

Não se aplica.

APROVAÇÃO DE COMITÊ DE ÉTICA EM PESQUISA

Não se aplica. 
LICENÇA DE USO

Este artigo está licenciado sob a Licença Creative Commons CC-BY. Com essa licença você pode compartilhar, adaptar, criar para qualquer fim, desde que atribua a autoria da obra.

HISTÓRICO

Recebido em: 30-09-2020

Aprovado em: 23-10-2020 